\title{
X-linked incontinentia pigmenti or Bloch-Sulzberger syndrome: a case report
}

\author{
Incontinência pigmentar ligada ao X ou síndrome de Bloch-Sulzberger: \\ relato de um caso
}

\author{
Marcela A. C. Pereira ${ }^{1}$ \\ Anelise R. Budel ${ }^{3}$ \\ Amanda de S. Feltrim ${ }^{5}$
}

Lismary A. de F. Mesquita ${ }^{2}$

Carolina S. P. Cabral ${ }^{4}$

\begin{abstract}
Incontinentia pigmenti is a rare X-linked genodermatosis that affects mainly female neonates. Skin manifestations are the most common and occur in four quite distinct phases. A female infant presented vesiculobullous lesions on trunk and limbs, and a verrucous lesion on the right palm. Biopsy revealed eosinophil exocytosis and pigment incontinence, confirming the clinical hypothesis. Although uncommon, incontinentia pigmenti should be taken into consideration as a possible differential diagnosis when vesiculobullous and verrucous lesions are present in childhood.
\end{abstract}

Keywords: genetics; incontinentia pigmenti; $\mathrm{X}$ chromosome

\begin{abstract}
Resumo: A incontinência pigmentar é uma genodermatose rara, ligada ao X, que afeta, principalmente, neonatos do sexo feminino. As manifestações cutâneas são as mais prevalentes, e ocorrem em quatro fases bem distintas. Lactente feminina com lesões vesicobolhosas em tronco e membros e lesão verrucosa em palma. À biopsia, observou-se exocitose eosinofílica e derrame pigmentar, compatível com a suspeita clínica. Apesar de incomum, a incontinência pigmentar deve ser lembrada entre os diagnósticos diferenciais, de lesões vesicobolhosas e verrucosas da infância.
\end{abstract}

Palavras-chave: Cromossomo X; Genética; Incontinência pigmentar

\section{INTRODUCTION}

Incontinentia pigmenti or Block-Sulzberger syndrome is a rare, dominant, $\mathrm{X}$-linked genodermatosis caused by a mutation in the NF-kappa B essential modulator (NEMO) gene of the kappa $\mathrm{B}$ genetic factor (nuclear kappa B essential modulator), located in the q28 portion of this chromosome. ${ }^{1}$ The term incontinentia pigmenti originates from the microscopic appearance of the lesions in the third phase of the disease, which is characterized by the presence of loose pigment in the basal layer of the epidermis, as if the melanocytes showed melanin-incontinence. ${ }^{2}$

The syndrome was first described by Garrod et al. in 1906 and then in identical twins by Bardach in 1925. In 1926, Block presented a further case to the Swiss Society for Dermatology and referred to this new clinical condition as incontinentia pigmenti. In 1928 , Sulzberger also reported the syndrome. ${ }^{3}$

The condition affects predominantly female newborns. When males are affected, it is generally lethal, resulting in spontaneous abortion in the majority of cases. Nevertheless, cases have been reported of male patients with Klinefelter syndrome or patients with a mosaic karyotype for this syndrome. ${ }^{1,3}$ In a review of the international literature, Carney reported that of 653 patients with incontinentia pigmenti, only 16 were male. ${ }^{4}$

In the present report, the authors describe a case of incontinentia pigmenti in a female infant referred to the dermatology outpatient clinic of a university teaching hospital because of vesiculobullous and verrucous skin lesions present since she was two

Received on 20.04.2009.

Approved by the Advisory Board and accepted for publication on 08.05.09.

* Study conducted at the Dermatology Department of the Evangelical Teaching Hospital, Curitiba, Paraná, Brazil.

Conflict of interest: None / Conflito de interesse: Nenbum

Financial funding: None / Suporte financeiro: Nenbum

Physician currently undergoing a specialist program, Evangelical Teaching Hospital, Curitiba, Paraná, Brazil.

Pathologist, Santa Casa de Misericórdia Hospital, Curitiba, Paraná, Brazil.

Professor of Dermatology, Curitiba Evangelical School of Medicine, Curitiba, Paraná, Brazil.

Physician currently enrolled in the doctorate program at the Curitiba Evangelical School of Medicine, Curitiba, Paraná, Brazil.

Physician currently enrolled in the doctorate program at the Curitiba Evangelical School of Medicine, Curitiba, Paraná, Brazil. 
weeks old. The reason for reporting this case is the rarity of the genodermatosis in question, which presents cutaneous and extracutaneous manifestations.

\section{CASE REPORT}

A four-month-old female patient, LHPT, from Almirante Tamandaré in Paraná, Brazil, was brought to the dermatology outpatient clinic by her mother because of skin lesions. The infant had had linear vesiculobullous skin eruptions with an erythematous base on her trunk and upper and lower limbs since the first few weeks of life and a verrucous, hyperkeratotic lesion on the palm of her right hand (Figures 1 and 2). No other alterations were detected at examination. She had been submitted to various treatments with topical and systemic antibiotics and antifungal medications, albeit without success. The patient was born at full-term by vaginal delivery and her mother reported no complications during her prenatal care and no similar cases in the family.

Biopsy revealed eosinophil exocytosis and pigment leakage, findings indicative of incontinentia pigmenti, although they are not specific to this dermatosis. A keratolytic emollient lotion and hydrocortisone were prescribed for short term treatment of the more erythematous lesions. Ophthalmological and neurological evaluations were normal. Over some months, the bullous lesions turned into verrucous lesions and then to residual hyperpigmentation in Blaschko's lines and few verrucous lesions (Figure 3). Currently almost a year old, the patient is now being followed up by a multidisciplinary team on an outpatient basis.

\section{DISCUSSION \\ Etiology}

In the majority of cases, this chromosomal

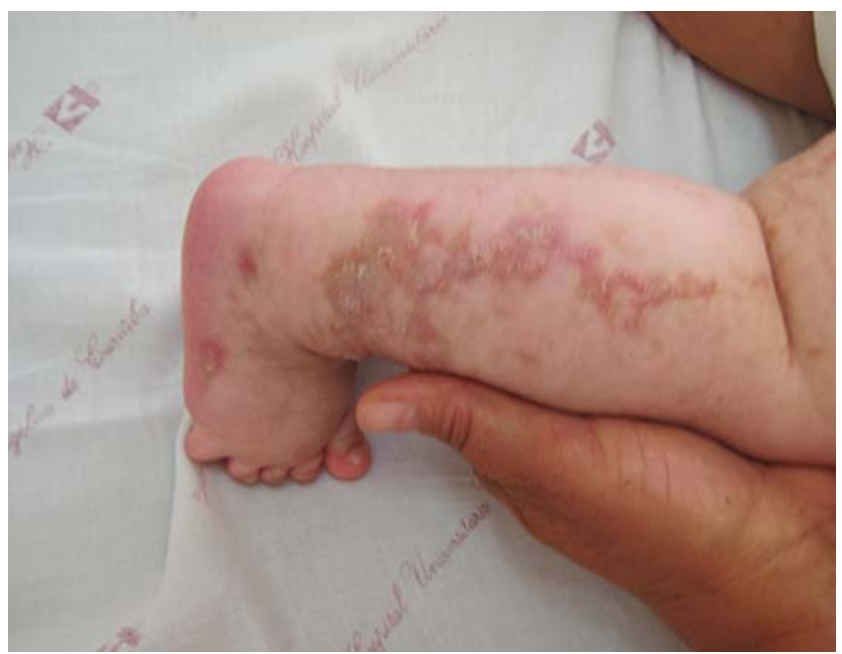

FigURE 1: Linear vesiculobullous skin eruption with erythematous base in right leg.

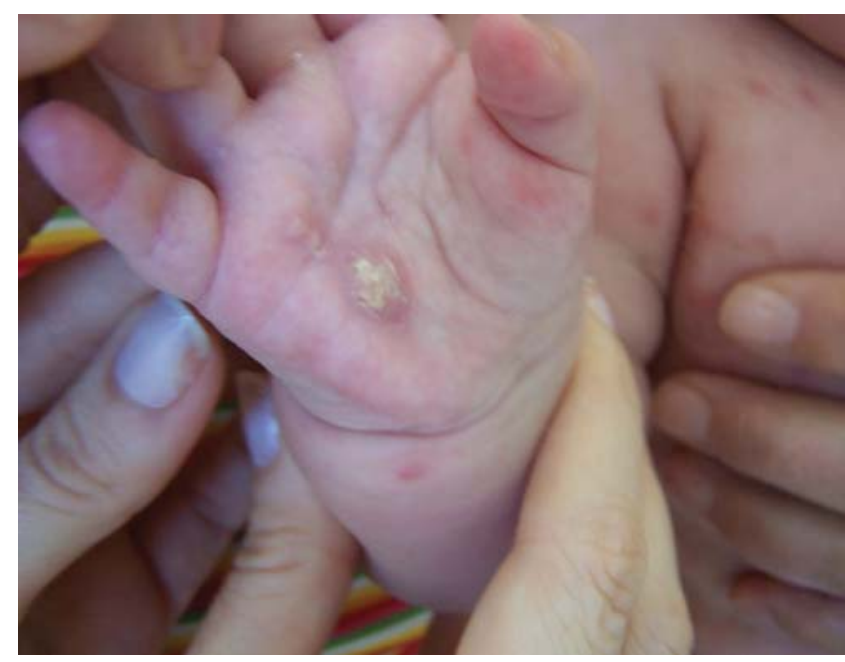

FiguRE 2: Verrucous, hyperkeratotic lesion on the right palm

defect is believed to occur in the long arm of the Xq28 chromosome. Approximately $80 \%$ of patients with incontinentia pigmenti have a deletion involving exons 4 and 10 of the NEMO gene. ${ }^{1}$ On the other hand, some investigators have found abnormalities in the short arm of chromosome Xp11. The exact cause of incontinentia pigmenti remains to be clarified. ${ }^{4}$

\section{Clinical manifestations}

The syndrome involves organs and tissues whose embryonic origin is ectodermal and mesodermal. Manifestations may be cutaneous or extracutaneous, the former being more common. In the majority of cases, these abnormalities present in the first few weeks of life and their progression is divided into four phases.

Progression of the cutaneous symptoms occurs in four classic phases that may be concomitant or sequential: 1 ) vesicles or linear inflammatory bliste-

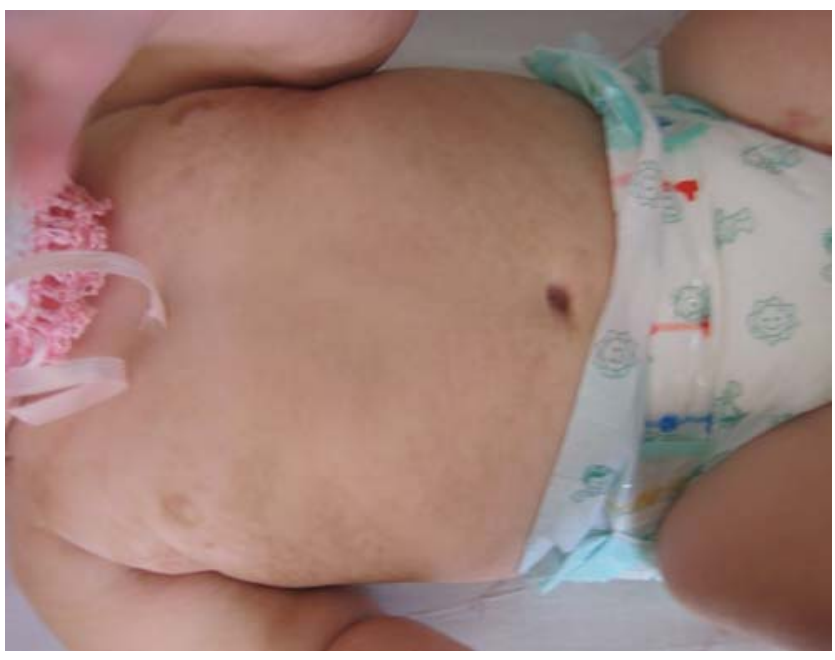

Figure 3: Residual hyperpigmentation in Blaschko's lines 
ring that appear at birth or during the first two months of life and may last weeks or months; 2) hyperkeratotic, verrucous, linear plaques that may last several months; 3) brown or greyish-blue hyperpigmentation, distributed in Blaschko's lines or in swirling patterns that appear in infancy and fade slowly until they disappear sometime in adulthood; 4) hypopigmented linear macules with no skin appendages on the trunk and limbs, appearing in adulthood. ${ }^{5}$ Some investigators describe only three phases, since the fourth phase may occur later and remain underdiagnosed. ${ }^{6}$

The skin manifestations may mimic many diseases, depending on the phase of progression. In the first phase, differential diagnosis should be made with bullous systemic lupus erythematosus and juvenile bullous pemphigoid; in the second phase with epidermolytic hyperkeratosis, hyperkeratosis associated with skin infections and lichen striatus; in phase 3 with nevoid hypermelanosis, dermatopathia pigmentosa reticularis, Naegeli-Franceschetti-Jadassohn syndrome and X-linked chondrodysplasia punctata, and in phase 4 with hypomelanosis of Ito and congenital aplasia cutis. ${ }^{3,4}$ Other skin manifestation described are alopecia, onychodystrophies and nail tumors. ${ }^{7}$ These tumors are rare; however, they may be confused with verruca vulgaris, epidermoid cyst, keratoacanthoma, squamous cell carcinoma, fibroma or chronic paronychia. Montes et al. reported two cases of subungual tumors in a mother and her daughter with incontinentia pigmenti. ${ }^{6}$

Extracutaneous manifestations occur in around $70-80 \%$ of cases and involve: the central nervous system (seizures, mental retardation, ischemic cerebrovascular accidents, hydrocephaly and anatomical abnormalities); eyes (strabismus, cataracts, anophthalmia, microphthalmia and others); teeth (hypodontia and partial anodontia, among others); bone and musculoskeletal structure (syndactylia, skull deformities, nanism, supernumerary ribs, hemiatrophy and shortening of the legs and arms). ${ }^{3,4,7,8}$ There have also been reports of immunological abnormalities such as leukocytosis and eosinophilia in the first phase, as well as poorly functioning lymphocytes and defective neutrophil chemotaxis. ${ }^{4,9}$

\section{Pathological diagnosis}

Diagnosis is based on clinical status and histological findings, which differ in each phase of progression of the disease. ${ }^{3}$ In the vesiculobullous phase, blisters full of eosinophiles are present; in the verrucous phase, hyperkeratosis, dyskeratosis, acanthosis and papillomatosis are present; in the hyperpigmentation phase, there is evidence of pigment leakage and numerous melanophages are present in the dermis; and in the hypopigmentation phase, there is a thinning of the epidermis and an absence of skin appendages. ${ }^{4,9,10}$

\section{Other supplementary tests}

Neuroimaging tests may be useful in symptomatic patients; however, they are not routinely performed; therefore, the frequency of neurological abnormalities in these patients remains unknown. Many radiologists may be unfamiliar with the radiological abnormalities present in this syndrome; hence the clinician should suggest the diagnosis based on the correlation between clinical and radiological findings. ${ }^{8}$

Fluorescent in situ hybridization may reveal underlying genetic abnormalities in male patients with incontinentia pigmenti and a normal karyotype.

\section{Treatment}

The management of the skin and systemic abnormalities in incontinentia pigmenti is based on symptomatology alone. Support and corrective measures may be used whenever possible. ${ }^{3,9}$

\section{Follow-up}

The skin lesions generally regress spontaneously. However, there have been reports of the appearance of dental and neurological abnormalities after childhood, which justifies the continued follow-up of these patients. ${ }^{9}$ Moreover, the male patients with incontinentia pigmenti who survive after birth have Klinefelter syndrome or a mosaic karyotype for this syndrome, and physicians and the patient's family must be prepared for possible related complications. ${ }^{1}$

\section{CONCLUSION}

Incontinentia pigmenti is difficult to diagnosis and there are many differential diagnoses for each phase of progression of the disease. The need should be emphasized for the dermatologist to recognize the abnormalities typical of each phase to ensure that the child is adequately managed and that his/her family is provided with appropriate information on the subsequent phases of the disease and possible abnormalities in other systems of the body. 


\section{REFERENCES}

1. Franco LM, Goldstein J, Prose NS, Selim MA, Tirado CA, Coale MM, et al. Incontinentia pigmenti in a boy with XXY mosaicism detected by fluorescence in situ hybridization. J Am Acad Dermatol. 2006;55:136-8.

2. Escobedo J. Incontinentia Pigmenti without Systemic Malformations: a case report and description for primary care clinicians. Proceedings of UCLA Health Care. 2000;4:10-2.

3. Ormond DT, Gamonal SB, Gamonal A, Carvalho MT. Condiloma de Buschke Lowenstein em paciente com incontinência pigmentar. An bras Dermatol. 1998;73:29-32.

4. Tristão OC, Baraky AKC, Carvalho MTF, Pereira CAC. Incontinentia pigmenti - síndrome de Block-Sulzberger: relato de caso. An Bras Dermatol. 1995; 70:231-3.

5. Lamounier FMC, Mansur CA, Corrêa, GM, Mansur JS, Mansur LA. Incontinência pigmentar: relato de dois casos. An Bras Dermatol. 2001;76:73-8.

6. Montes CM, Maize JC, Guerry-Force ML. Incontinentia pigmenti with painful subungual tumors: a twogeneration study. J Am Acad Dermatol. 2004;50:S45-52.

7. Krebs VL, Silva CH, Rivitti E, Vaz FA. Incontinência pigmentar: relato de um caso. Pediatria. 1983;5:55-60.

8. Mirowski GW, Caldemeyer KS. Radiologic.Incontinentia pigmenti. J Am Acad Dermatol. 2000;43:517-8.

9. Pacheco TR, Lewy M, Collyer JC, Parra NP, Parra CA, Garay $M$, et al. Incontinentia pigmenti in male patients. J Am Acad Dermatol. 2006;55:251-5.

10. Clemons E, Clemons D, Lee JA, Berne S. Incontinentia pigmenti in three generations: A case report. J Am Acad Dermatol. 2008;58:AB80.

MAILING ADDRESS / ENDEREÇO PARA CORRESPONDÊNCIA: Dra. Marcela A. C. Pereira Avenida Sete de Setembro, 6700 80240 001, Curitiba - PR, Brazil Pbone./fax: 4130775050 Cel.: 4199663610 e-mail:dra_marcela@yaboo.com.br

How to cite this article/Como citar este artigo: Pereira MAC, Mesquita LAF, Budel AR, Cabral CSP, Feltrim AS. Xlinked incontinentia pigmenti or Bloch-Sulzberger syndrome: a case report. An Bras Dermatol. 2010;85(3):372-5. 